Intervenção Problematizadora no Ensino de Química: um Relato de Experiência

\author{
Leite, V. C.; ${ }^{*}$ Soares, M. H. F. B.
}

Rev. Virtual Quim., 2015, 7 (3), 1007-1029. Data de publicação na Web: 20 de maio de 2015

http://www.uff.br/rvq

\title{
Problematizing Intervention in the Teaching of Chemistry: an Experience Report
}

\begin{abstract}
The achievement of the practice of freedom covers an essential task which comes up when the lesson is structured from participative actions that lead to freedom of expression and critics, without the imposition of knowledge to students. We report the praxis in the sphere of Graduation in Chemistry, for supervised academic training course. This topic has been used as theme by the problematizing teaching with High School students. The proposition we have developed through a problematizing bias has shown to be relevant for the students as well as for the interns who took part of the activity. The process added to the ensemble of knowledge of students and interns, a method of studying and a method of critical reading of reality with relevant consequences for the formation of both interns and students as critical citizens.
\end{abstract}

Keywords: Problematizing teaching; Teacher formation; Teaching of chemistry.

\section{Resumo}

A conquista da prática da liberdade compreende uma tarefa essencial que aparece quando a aula é estruturada a partir de ações participativas que levam à liberdade de expressão e crítica, sem a imposição de saberes aos alunos. Relatamos a práxis no âmbito de um curso de Licenciatura em Química, na disciplina de estágio supervisionado. O mesmo foi tematizado pela educação problematizadora com alunos do ensino médio, envolvendo a análise qualitativa de caráter descritivo dos fatos. A proposta desenvolvida com o princípio problematizador mostrou-se pertinente, tanto para os alunos quanto para os estagiários que participaram da atividade. O processo veio acrescentar no conjunto de saberes de ambos, um método de estudo e de leitura crítica da realidade com consequências relevantes para a formação do estagiário e do aluno como cidadão crítico.

Palavras-chave: Educação problematizadora; Formação de professores; Ensino de química.

\footnotetext{
* Instituto Federal de Goiás, Av. Pedro Ludovico, s/n, Reny Cury, CEP 75131-457, Tel.: +55-6233102800, Anápolis-GO, Brasil.

$M$ vanessacarneiroleite@gmail.com

DOI: $\underline{10.5935 / 1984-6835.20150055}$
} 


\title{
Intervenção Problematizadora no Ensino de Química: um Relato de Experiência
}

\author{
Vanessa C. Leite, ${ }^{a, *}$ Márlon Herbert F. B. Soares ${ }^{b}$ \\ ${ }^{a}$ Instituto Federal de Goiás, Av. Pedro Ludovico, s/n, Reny Cury, CEP 75131-457, Tel.: +55-62- \\ 33102800, Anápolis-GO, Brasil. \\ ${ }^{\mathrm{b}}$ Universidade Federal de Goiás, Campus Samambaia, CP 131, CEP 74001-970, Tel.: +55-62- \\ 35211097 (Ramal 209), FAX: +55-62-35211167, Goiânia-GO, Brasil. \\ * vanessacarneiroleite@gmail.com
}

Recebido em 19 de maio de 2015. Aceito para publicação em 19 de maio de 2015

\section{Introdução}

1.1. Educação bancária e a educação problematizadora no contexto da sala de aula

1.2. Educação problematizadora como prática da liberdade

\section{Percurso Metodológico da Pesquisa}

\section{Resultados e Discussão}

3.1. O contexto dos alunos do ensino médio

3.2. Planejamento da situação-problema

3.3. Estratégia educativa relacionada à problematização: "A Chuva Ácida não contém somente Água"

\section{Considerações Finais}

\section{Introdução}

A problematização na educação vem sendo trabalhada dentro de muitas perspectivas pedagógicas, incluindo trabalhos de pesquisa em áreas como a Física, Química e Saúde. Nesses trabalhos, muitos apresentam apenas como uma resolução de problemas em si, sem o envolvimento de questões sociais, culturais e políticas que intencionem buscar a consciência crítica sobre o assunto trabalhado. Neste sentido, este estudo busca levantar alguns aspectos da educação problematizadora desenvolvida durante o estágio supervisionado num colégio estadual de Goiânia-Go, com o intuito de auxiliar o professor no planejamento e desenvolvimento de aulas a partir da educação problematizadora.

1.1. Educação bancária e a educação problematizadora no contexto da sala de aula

$\mathrm{Na}$ relação aluno-professor, é possível perceber um caráter especial e marcante, o de serem relações fundamentalmente 
narradoras ou dissertadoras. ${ }^{1}$ A narração de conteúdos implica um sujeito, considerado como narrador, e os objetos pacientes ou ainda ouvintes, os alunos. Essa forma de "despejar" informações ou comunicados está sempre presente na sala de aula, e consiste na transmissão de eventos na forma de palavras e que na maioria das vezes considera a realidade como algo parado, estático ou alheio à experiência existencial dos alunos. A palavra se torna oca, porque se esvazia da dimensão concreta, e se transforma em verbosidade alienada e alienante, levando os alunos à memorização mecânica do conteúdo narrado. Nessa relação pouco respeitosa, o professor atua como sujeito e tem a função de "encher" os alunos de conteúdos:

"Em lugar de comunicar-se, o educador faz "comunicados" e depósitos que os educandos, meras incidências, recebem pacientemente, memorizam e repetem. Eis aí a concepção "bancária" da educação, em que a única margem de ação que se oferece aos educandos é a de receberem os depósitos, guarda-los e arquivá-los.". ${ }^{1}$

Esse modelo de ensino vem sendo repetido nas últimas décadas por educadores de forma constante e logo ficou conhecido como sendo a "educação bancária", educação que impõe o conhecimento realizado pelo professor sobre o aluno na medida em que o professor dispõe destes sendo assim possível sua ação de depósito nos alunos. A educação bancária representa a relação entre opressor-oprimido e o interesse maior é manter o status quo, ${ }^{2}$ relação essa estritamente verticalizada, verbalista e autoritária, na qual os professores se consideram superiores pelo fato de deterem o conhecimento. Na prática, as aulas desenvolvidas procuram evitar debates e discussões que levem a contradições e formação de opiniões, o que favorece o sistema de dominação. Contrária a essa prática surge a educação libertadora, também denominada de educação problematizadora que tem como fundamento a relação participativa do aluno que passa a interferir na realidade modificando-a, saindo da posição de espectador e se integrando em seu contexto, criando e recriando, respondendo a seus desafios. $^{3}$ Fundamentadas na pedagogia freireana, ${ }^{4}$ apresentamos algumas diferenças entre a educação bancária e a educação problematizadora, como mostra a Tabela 1:

Tabela 1. Diferenças entre Educação Bancária e Educação problematizadora

\begin{tabular}{cc}
\hline Educação Bancária & Educação Problematizadora \\
\hline - Conhecimento transmitido: relação & - Conhecimento crítico: relação horizontal; \\
vertical classista; & - Aluno e educador: sujeitos cognoscentes; \\
- Aluno: objeto sem conhecimento; & - Educação: ato participativo, superação do \\
- Educador: sujeito & conhecimento construído, o aluno aprende \\
- Educação: ato mecânico, o aluno se & adapta a realidade imposta.
\end{tabular}

O ato mecânico valorizando a memorização e a transmissão de informações faz o conhecimento surgir a partir de uma relação verticalizada de adaptação, ignorando os aspectos sócio-políticos envolvidos na ação de educar. Nessa relação o professor se considera superior ao aluno que se mantém passivo frente aos "depósitos" de informações recebidas, sendo assim "O professor é um ser superior que ensina a ignorantes. Isto forma uma consciência bancária. $O$ educando recebe 
passivamente os conhecimentos, tornandose um depósito do educador.". ${ }^{5}$

Sendo assim, afirmamos que a educação não pode ser um processo de adaptação do indivíduo à sociedade. Ao adaptar o homem à educação eliminamos as possibilidades de ação e de sua capacidade de "ser mais" e transformar a realidade. ${ }^{6} \mathrm{Na}$ visão bancária de ensino, o "saber" é uma doação daqueles que sabem mais e procuram deixar isso bem claro dentro da sala de aula como forma de evitar questionamentos e concretizar a ideologia de opressão: "na visão "bancária" da educação, o "saber" é uma doação dos que se julgam sábios aos que julgam nada saber". ${ }^{7}$

Contrariando essa forma de ensinar, a educação problematizadora naturalmente transforma $\mathrm{o}$ ato participativo em conhecimento dinâmico e importante para o aluno, que é reconhecido como sujeito pela sua capacidade de transformar e aprender junto, assim como o professor. ${ }^{7}$ A relação entre aluno-professor é horizontal, ou seja, relação sustentada e motivada pelo respeito do conhecimento do outro que não é melhor daquele que hora se coloca na posição de ensinar e de aprender. O professor na pedagogia problematizadora promove nos alunos o espírito crítico, a curiosidade e o conhecimento questionador. É considerado um ser inacabado na relação educadoreducando e educando-educador, por isso educa e está em constante processo de busca e superação. Nesse sentido, "a educação, portanto implica uma busca realizada por um sujeito que é o homem. $O$ homem deve ser sujeito de sua própria educação. Não pode ser o objeto dela. Por isso ninguém educa ninguém". ${ }^{7}$

A pedagogia problematizadora não nasceu de forma abstrata somente nos livros, surgiu como práxis, vivida por Paulo Freire junto a grupos de "analfabetos". ${ }^{4}$ O conhecimento construído por ele começava da prática para à teoria para entendê-la melhor e transformá-la. Sua proposta teóricometodológica foi um encontro dialógico que permitiu entender que a leitura do mundo antecede a leitura da palavra e que ler e escrever é pronunciar o mundo para relê-lo e reescrevê-lo, possibilitando a transformação de todos os envolvidos. Nesse contexto, a pedagogia freireana define a educação problematizadora como sendo a práxis político-pedagógica, ou seja, a ação e reflexão crítica sobre a educação que se desenvolve com os alunos e que surge a partir de uma proposta dialógica.

No diálogo democrático não falamos "para", como quem é detentor de um saber indiferente às críticas, postura inerente de quem não dialoga com a intenção de perceber e apreender o mundo de forma integral, mas falamos "com", na certeza que a educação amplia a visão de mundo contribuindo na formação para a cidadania, para a vida ou para sua inserção na sociedade. $^{7} \mathrm{Na}$ visão de alguns pesquisadores, enquanto a educação bancária humilha o aluno, a educação problematizadora dá a dignidade, o respeito ao educando, colocando o professor ao seu lado com a tarefa de orientar e coordenar o processo educativo como um ser que também busca conhecer e aprender. ${ }^{8} \mathrm{E}$ através do diálogo, o conhecimento é construído de forma integradora e interativa, não é tratado como algo pronto e acabado que apenas precisa ser apropriado ou socializado com os alunos, como sustenta a educação bancária.

No contexto da escola atual, o conhecimento vem sendo trabalhado através de um ensino tradicional, e entre as várias áreas do conhecimento, é associado à Química a ideia de uma disciplina enfadonha, distante da realidade e de toda a dinâmica envolvida em seu estudo crítico. Esse fato está fundamentado num modelo de ensino neoliberal, caracterizado pela formação de professores que concebem a ideia de que para ensinar basta "passar" e cumprir o conteúdo programático. $^{10} \mathrm{O}$ ensino tradicional vem sendo criticado por Paulo Freire: 
"O educador faz "depósitos" de conteúdos que devem ser arquivados pelos educandos. Desta maneira, a educação se torna um ato de depositar, em que os educandos são os depositários e o educador o depositante. 0 educador será tanto melhor educador quanto mais conseguir "depositar" nos educandos. Os educandos, por sua vez, serão tanto melhores educados, quanto mais conseguirem arquivar os depósitos feitos.". ${ }^{3}$

Nesse sentido, o ensino de química é permeado pelo tradicionalismo, destacandose as técnicas de memorização de regras, fórmulas, nomes e estruturas, além de apresentar os conteúdos distanciados da realidade dos alunos. Com características de uma ciência exclusivamente teórica, a Química assim apresentada aos alunos, tem gerado sentimentos de desmotivação e desinteresse. Esse ensino vem fazendo parte de grande parte das escolas brasileiras calcado no processo simples de transmissão de informações, de conceitos e de leis isoladas. $^{9}$

Ao repensar a Química, se discute a necessidade de superar a "transmissão", proporcionando um ensino que de fato leve a aprendizagem, e para isso o professor não pode se satisfazer com a repetição de definições ou exemplos dos alunos, usando apenas fórmulas ou palavras vazias de significados. ${ }^{10}$

"Muitos educadores/professores, através de suas aulas, ou autores, através de seus livros, pensam poder 'transmitir' ou 'transferir' seus próprios conceitos de química para seus alunos, por meio de definições do que seja matéria, energia substância, reação química, fenômeno químico, fenômeno físico. O resultado dessa proposta de ensino de química é bem conhecido!". ${ }^{10}$

Dentro da concepção de cidadania, o ensino de química deve superar a simples transmissão de conhecimentos mediante o desenvolvimento dos valores éticos, com os interesses da sociedade democrática que idealizamos. Devemos eliminar a concepção ingênua de que ao ensinar química estamos educando cidadãos, pois não basta ensinar conceitos químicos, ensinar a Química pela Química, é preciso ampliar as ações mediante uma educação de valores morais. O modelo de ensino transmissão-recepção pode ser superado se ocorrer o envolvimento do professor crítico como mediador, motivando o aluno a ser participativo, deixando de ser concebido e tratado apenas como tábula rasa. $E$ isso significa que, sem 0 envolvimento do aluno, muito pouco a escola pode contribuir na consolidação da cidadania: ${ }^{11}$

"No contexto das pesquisas educacionais realizadas no Brasil e referentes ao ensino de Química em particular, cresce o número daquelas pesquisas que têm o propósito de superar um ensino distanciado do contexto local dos estudantes. Ensino esse baseado comumente no modelo de transmissão de conhecimentos e com fins memorísticos, que superdimensionam o ensino de conceitos em detrimento de outros objetivos educacionais mais ligados à formação científica para o exercício da cidadania.". ${ }^{11}$

A prática de ensino desenvolvida pelo professor manifesta quase que exclusivamente a retenção, por parte do aluno, de enormes quantidades de informações, com o propósito de que essas sejam memorizadas e devolvidas nos mesmos termos em que foram apresentadas durante as avaliações. Alguns estudiosos afirmam que o ensino passa a imagem de um conhecimento científico de neutralidade empírica, a-histórico, exclusivamente analítico, cumulativo e linear, elitista, individualista, descontextualizado e socialmente neutro. ${ }^{12,13}$ Os motivos que justificam estas questões estão ligados à formação de professores, a propagação de uma visão muito simplista da prática docente, de que sabendo o conteúdo e 
algumas técnicas pedagógicas bastam, visto que a função do ensino nessa perspectiva é apenas transmitir o conhecimento. A "Educação através da Química" revela o quanto o professor deve manifestar uma consciência de cidadania e a capacidade crítica de desenvolver um ensino que leve a formação de cidadãos também críticos. ${ }^{12}$ Para isso, não basta ser professor para transmitir conhecimentos de Química, é preciso que a educação deixe de ser um instrumento de dominação e passe a significar oportunidades de crescimento para os alunos e para o professor dentro de um processo participativo e emancipatório:

“Não vou comentar, e isto é desnecessário dizer, em vista das respostas às duas perguntas anteriores, que não se é professor de Química para transmitir conhecimentos de Química. Há, cada vez mais, uma preocupação na busca de ações mais intensas para que formemos profissionais que tenham uma "efetiva consciência de cidadania, independência de pensamento e capacidade crítica, que devem adquirir ao longo de sua formação acadêmica.". ${ }^{13}$

Portanto, se faz necessário repensar numa formação inicial que caminhe para uma aproximação reflexiva da realidade, criando a possibilidade da práxis numa perspectiva de ação e reflexão crítica do professor. E ainda que possibilite ao professor refletir sobre si mesmo, a ser consciente do que pensa e realiza na escola. Somente assim, o professor será capaz de transcender a sua atividade, dando sentido a tudo que participa, elaborando objetivos e propondo finalidades que levem ao estado de consciência crítica tanto do aluno quanto de sua identidade profissional.

\subsection{Educação problematizadora como prática da liberdade}

A conquista da prática da liberdade compreende uma tarefa essencial que aparece quando a aula é estruturada a partir de ações participativas que levam à liberdade de expressão e crítica dos alunos. ${ }^{3}$ Nesse processo de conquista, o professor jamais impõe os saberes aos alunos, esses são orientados e motivados a participar através da abordagem de temas conhecidos de situações existenciais. A palavra, nesse contexto, não é vista como um simples "dado" ou como uma doação do professor para o aluno, ela não existe independentemente de sua significação real, está sempre se referindo às situações vivenciadas por eles. Nesse sentido, a prática da liberdade e crítica perante as situações existenciais dentro do contexto escolar, leva a tomada de decisão, fazendo com que o aluno compreenda a sua situação social e passe a agir conscientemente. Com essa "pedagogia o aprendizado já é um modo de tomar consciência do real e como tal só pode dar-se dentro desta tomada de consciência.". ${ }^{3}$

$\mathrm{Na}$ educação problematizadora $\mathrm{O}$ professor passa de espectador e repetidor de informações, a sujeito de sua história, um ser de relações que através da postura de autorreflexão e reflexão crítica sobre suas condições atuais, é capaz de agir conscientemente "criando e recriando, integrando-se as condições de seu contexto.". ${ }^{3}$ Essa ação se manifesta em diálogos que o professor faz sobre e com o mundo, com seus problemas e desafios, com as dificuldades enfrentadas no âmbito escolar e na sociedade. Emerge desse processo, o trabalho pedagógico crítico que combate a antidemocracia proveniente de uma sociedade opressora e dominadora que desde muito tempo vem conduzindo o modelo de ensino transmissão-recepção dos professores em sala de aula. É certo que vivenciamos uma inexperiência democrática, ${ }^{3}$ o professor não sabe dialogar, esse ato não faz parte de nossa cultura e nossas raízes justificam o fato de não levarmos os alunos às experiências do debate e da análise de problemas que promovam condições verdadeiras de participação. Para Paulo 
Freire: "o Brasil nasceu e cresceu sem experiência de diálogo. De cabeça baixa, com receio da Coroa. Sem imprensa. Sem relações. Sem escolas. Doente.". ${ }^{3}$

A superação da inexperiência democrática leva à educação libertadora, para esse processo acontecer é preciso adotar a constante mudança de atitude, substituindo antigos hábitos de passividade por novos de participação e intervenção. Nesse sentido, precisamos repensar a formação de professores fundamentada em tradições fortemente "doadoras", para uma formação crítica que incentive o professor mediador, coordenador e articulador das discursões. $\mathrm{E}$ leve o aluno com tradições passivas, ao desenvolvimento de ações participativas, emergindo o aprendizado a partir da realidade reinventada. ${ }^{3}$

Defendendo que a educação libertadora conduz o professor a ser sujeito de seu pensar e que é capaz de discutir a sua própria realidade, os professores são encarados como sujeitos do conhecimento e não incidências do trabalho docente. ${ }^{3}$ Nesta perspectiva, opondo-se à educação "bancária", Paulo Freire define a sua prática na dialética educador-educando:

“A educação libertadora, problematizadora, já não pode ser o ato de depositar, ou de narrar, ou de transferir, ou de transmitir "conhecimentos" e valores aos educandos, meros pacientes, à maneira da educação "bancária", mas um ato cognoscente. Como situação cognosciológica, em que o objeto cognoscível, em lugar de ser o término do ato cognoscente, educador, de um lado, educando, de outro, a educação problematizadora, coloca, desde logo, a exigência da superação da condição educador-educando. Sem ela, não é possível a relação dialógica, indispensável à cognoscibilidade dos sujeitos cognoscentes, em torno do mesmo objeto cognoscível.". ${ }^{3}$

$\mathrm{Na}$ escola tradicional ouvimos muitas aulas onde não há nada além de uma transferência de conhecimento oral, um canal verbal para a transferência do conhecimento. ${ }^{14} \mathrm{O}$ professor faz preleções eruditas sobre sua matéria e os alunos copiam aquilo que ouvem, raramente são provocados por uma reinvenção criativa, que os obrigue a repensar a maneira de ver a realidade ou os motive para a ação. Já para Paulo Freire é importante esclarecer que ao criticar a educação bancária, temos que reconhecer que nem todas as aulas expositivas podem ser enquadradas nesse modelo de educação.

O professor pode ser muito crítico fazendo preleções, a questão é como fazer, ou seja, não tornar aquilo que o professor fala em uma canção de ninar para os alunos. As aulas expositivas ou coordenadas por discussões podem ser obscuras, isso depende de vários fatores: do grau de integração dos alunos, tornando a aula dinâmica e aberta a expressividade; o quanto a aula reorienta os alunos para a sociedade de forma crítica e se realmente estimula seu pensamento crítico.

$\mathrm{Na}$ educação problematizadora a fala do professor torna-se para o aluno um objeto de reflexão, uma espécie de codificação de um problema, que será decodificado pelos alunos e pelo próprio professor, levando ao ensino crítico. $\mathrm{O}$ ato de conhecer do conhecimento numa perspectiva de educação problematizadora, envolve dois momentos de um ciclo gnosiológico: o conhecer do conhecimento existente e o conhecer do conhecimento novo. ${ }^{14} \mathrm{O}$ ciclo gnosiológico mostra uma relação entre 0 conhecimento existente na qual o professor como mediador do ensino dialoga com os alunos despertando a curiosidade para o ato de aprender. Nesse sentido, a motivação em aprender leva-os ao questionamento exigente, e a partir dessa dinâmica estabelecida, integra os estudantes numa criação e recriação do conhecimento comumente partilhado, $\mathrm{o}$ conhecimento novo. Este surge a partir da prática e reflexão crítica sobre o conhecimento existente. Para gerar o conhecimento novo "é necessário, na situação educativa, educador e educando assumam o papel de sujeitos cognoscentes, 
mediatizados pelo objeto cognoscível que buscam conhecer". ${ }^{15}$

A problematização é referida como sendo atividades questionadoras e de diálogo, em que através da resolução de problemas, os alunos possam construir seu conhecimento. Essa proposta deve ser fundamentada na ação do aluno, ou seja, os mesmos devem ter a oportunidade de agir sem se limitar ao trabalho de manipulação ou observação. ${ }^{16} \mathrm{O}$ aluno deve refletir, discutir, explicar e relatar o trabalho que está realizando, e compreender a questão do problema como ponto de partida para o desenvolvimento de um novo conhecimento. E com a participação ativa do aluno na abordagem problematizadora o professor muda a sua postura, deixando de agir como transmissor do conhecimento, passando a agir como um mediador.

A dialogicidade é considerada uma das categorias centrais de um projeto pedagógico crítico e propositivo. ${ }^{1}$ Nesse sentido a proposta de intervenção na sala de aula, não poderia deixar de ser discutida com os estagiários para que através do diálogo possam olhar a educação como processo de uma realidade inacabada e em constante transformação. Segundo Paulo Freire, no diálogo aberto, no exercício da argumentação dos sujeitos participantes, as posições diferentes são ouvidas, debatidas e avaliadas. Portanto, o diálogo passa a ser a força que impulsiona o pensar críticoproblematizador em relação à condição humana no mundo e, através do diálogo, os estagiários podem dizer o modo de ver as relações estabelecidas na escola e fora dela. ${ }^{17}$ A partir do diálogo se pretende buscar a problematização dentro da realidade vivenciada pelos alunos para só assim compreender e transformar: ${ }^{15}$

"O que se pretende com o diálogo, é a problematização do próprio conhecimento em sua indiscutível reação com a realidade concreta na qual se gera sobre a qual incide, para melhor compreendê-la, explicá-la e transformá-la.". 15

Importante destacar que os estagiários, ao buscarem a problematização, utilizam uma metodologia que seleciona e organiza o conteúdo a ser trabalhado, a partir da realidade existencial do aluno, sem negar a dialogicidade e a conscientização no processo de aprender. Nesse caso, os estagiários devem ser incentivados ao diálogo, adquirindo a capacidade de agir e refletir. Somente assim o professor consciente criará possibilidades de intervenção que leve a reais mudanças no contexto escolar e social dos alunos. Nesse caso, "a primeira condição para que um ser possa assumir um ato comprometido está em ser capaz de agir e refletir". 6

Portanto, se torna necessário incluir nos currículos de formação de professores o desenvolvimento da práxis pedagógica, ou seja, da ação e reflexão crítica do professor. Promovendo uma formação que não se encerra em si mesma, mas se articula com diferentes esferas da formação e da práxis dos professores em suas diversas dimensões: sociais, políticas e acadêmicas. Nesse contexto, o estágio supervisionado compreende um bom começo para refletir criticamente sobre a prática existente dos professores. A superação da posição de meros executores das decisões, só se concretiza mediante o reconhecimento destes como sujeitos participantes das propostas para o sucesso na implantação de mudanças. $^{18}$

Além desse reconhecimento, o estágio supervisionado deve fornecer ao futuro professor, a capacidade de inserir-se na sociedade em que vai atuar, adquirindo uma postura ética, passando pela sensibilidade estética e pela consciência política. Nesse sentido, a universidade, ao preparar os professores, deve assegurar a formação integral buscando um compromisso éticopolítico. Nessa formação, o profissional torna-se sensível à dignidade humana, se comprometendo com a democratização das 
relações sociais, criando uma nova consciência social, que Paulo Freire chama de consciência crítica.

Nessa direção, a educação passa a ser multidimensional, ou seja, apresenta uma dimensão humana, dimensão técnica e dimensão político-social. Ao partir da perspectiva de educação como prática social inserida no contexto político-social determinado, essas dimensões se integram na prática cotidiana do futuro professor. Se traduzindo em comportamentos e atitudes concretas relativas aos objetivos propostos no contexto escolar, em que a prática não se reduz à dimensão técnica da educação. ${ }^{39}$

Neste sentido, relatamos uma intervenção problematizadora com estagiários do curso de licenciatura em Química, com o objetivo de conduzir ações que despertem o pensamento crítico e a autonomia intelectual dos discentes diante da realidade escolar.

\section{Percurso Metodológico da Pesquisa}

A pesquisa foi desenvolvida com 17 estagiários de uma Instituição privada da cidade de Goiânia - GO, nas disciplinas de Estágio I e Estágio II do curso de licenciatura em Química. O colégio estagiado pelos discentes se localiza em Goiânia, e compreendeu o local de discussão e desenvolvimento da aula problematizadora. A pesquisa foi conduzida pela abordagem qualitativa de caráter descritivo e os dados recolhidos a partir de entrevistas semiestruturadas. Essa intervenção buscou alcançar processos de interação entre o estagiário e a escola, almejando as mediações simbólicas que se figuram pelas percepções do estagiário que vivencia a escola e o fenômeno a ser estudado. Para a coleta de dados utilizou-se entrevistas gravadas e transcritas, além de questionário aplicado aos alunos do ensino médio. O referencial teórico se baseia nos pressupostos de Paulo Freire e sua pedagogia libertadora, considerando a princípio o contexto dos alunos do ensino médio e o planejamento da situação-problema pelos estagiários.

\section{Resultados e Discussão}

\subsection{O contexto dos alunos do ensino médio}

Apesar de algumas questões em branco, os questionários respondidos trouxeram a compreensão do pensamento dos alunos em relação ao ensino de química que recebem. Nesse contato, oportunizamos aos alunos dizerem os problemas que impedem uma maior aprendizagem e o que poderia ser melhorado no ensino de química. 0 questionário compreendeu um documento de valor para a tomada de decisões frente às ações dos estagiários na escola. Conhecer o que os alunos pensam e esperam do ensino de química coaduna com a prática pedagógica freireana. Essa prática pretende, de forma reflexiva e aberta, iniciar o processo de aprendizagem levando em consideração o "ser aluno". Nesse sentido, o aluno é sujeito da sua história de aprendizagem e ao mesmo tempo objeto desse processo, sua ótica e impressões de vida contribuem para desatar os nós da educação e em especial do ensino de química.

Inicialmente foi aplicado um questionário contendo cinco questões discursivas (Figura 1), aos alunos das três séries (1으, 2으 e 3ㅇano) do ensino médio, com o objetivo de conhecer algumas das concepções dos alunos e a partir delas, elaborar o tema gerador e a aula problematizadora. Conhecer o que os alunos pensam e esperam do ensino de química coaduna com a prática pedagógica freireana que pretende de forma reflexiva e aberta, iniciar o processo de aprendizagem levando em consideração o "ser aluno". 
1. Quais os maiores problemas que você percebe nas aulas de química?

2. Se dependesse de você para melhorar as aulas de química, o que você faria?

3. Pense em temas ou assuntos que você gostaria de estudar ou tem curiosidade em aprender sobre química e mencione-os.

4. As aulas de química ajudam a responder tudo àquilo que você não sabe em seu cotidiano? Cite exemplos.

5. Reflita sobre as questões abaixo e mostre qual o maior problema que você percebe nas aulas de química. Explique.

- Atividades pouco criativas e participativas;

- Falta de domínio de conteúdo;

- Professor sem diálogo;

- Ensino descontextualizado e pouco interessante;

- Indisciplina na sala de aula.

Figura 1. Questionário aplicado aos alunos do ensino médio

O número de questionários respondidos pelos alunos nas três séries aplicadas totalizou 94 questionários. Na primeira questão, a resposta dada pelos alunos mostra que o maior problema nas aulas de química, está relacionado ao desinteresse e a indisciplina dos alunos $(33,0 \%)$, na sequência
$26,0 \%$ dos alunos responderam outro tipo de resposta ou não responderam, $22,0 \%$ dos alunos apontaram dificuldades na compreensão do conteúdo. $E$ a falta de aulas práticas $(6,0 \%)$ também foi apontada pelos alunos do ensino médio como mostra a Figura 2:

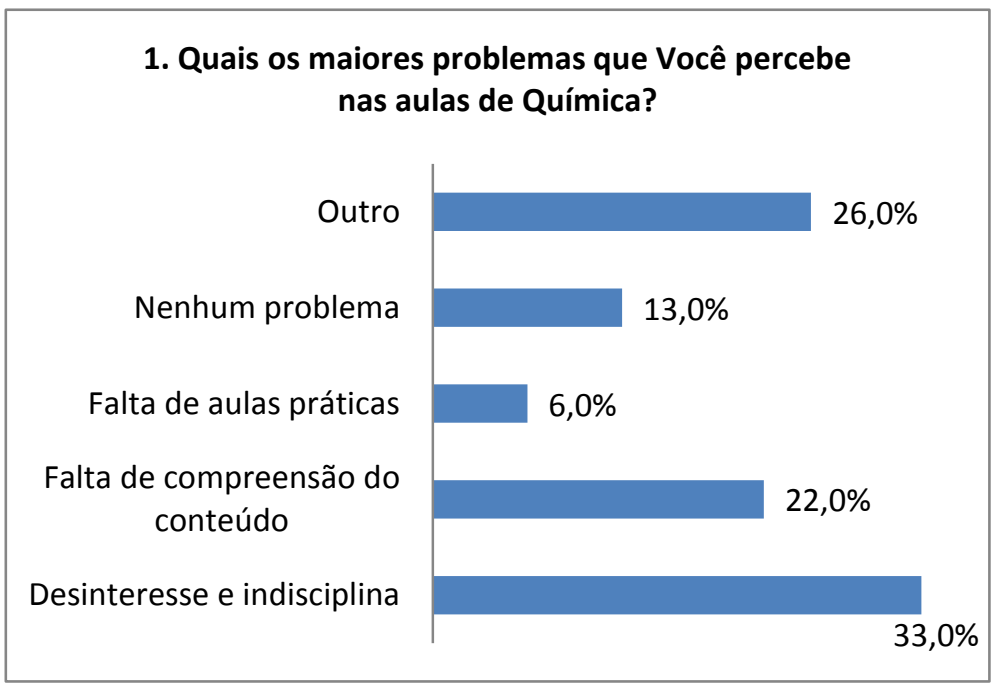

Figura 2. Resultado percentual das respostas dadas a questão 1 do questionário respondido pelos alunos do ensino médio. "Outro" representa respostas diversas ou os alunos não responderam

Para discutirmos sobre a falta de interesse como problema presente na sala de aula, recorremos a estudiosos que diferenciam interesse e motivação. ${ }^{20} \mathrm{O}$ interesse prende a atenção do aluno ao se referir as coisas que Ihe interessa já a motivação possui a força suficiente para conduzir o aluno a realizar a atividade proposta. Essa diferença é 
percebida quando, por exemplo, o professor prepara uma atividade que acredita chamar atenção dos alunos e que os levaria a construção do conhecimento, porém ao executá-la não consegue o envolvimento esperado. Neste caso, os alunos podem até ter tido interesse, mas não tiveram a motivação suficiente para desenvolver a atividade. A motivação do aluno está relacionada com o contexto específico da sala de aula, com isso deve se contemplar e integrar os componentes próprios de seu contexto na abordagem dos assuntos que se pretende trabalhar com os alunos. ${ }^{20}$

Atualmente percebe-se que os alunos mantêm maior interesse aos recursos de comunicação (celular e seus aplicativos), do que no assunto desenvolvido pelo professor. Nesse contexto, a escola deve reconhecer que essa nova geração de alunos vive em um mundo no qual o apelo ao visual, à imagem é atraente e recorrente, com isso modifica de forma relevante, seu modo de ver e compreender a realidade. ${ }^{21}$ A falta de compreensão do conteúdo pode ser uma consequência do desinteresse e da indisciplina na sala de aula, que também se justifica pelo ensino exclusivamente verbalista de mera transmissão de informações. Algumas falas fazem referência ao desinteresse dos alunos (A1, A2, A3... se referem às falas transcritas dos alunos do ensino médio):

A1: "O desinteresse dos alunos, não é só em química, mas em várias matérias".

A2: "Vejo problemas não da parte do professor, nem conteúdo, e sim falta de interesse e respeito de alguns alunos, que não gostam da matéria".

O professor no ensino tradicional apresenta o conteúdo partindo de definições, exemplos, demonstrações de propriedades, seguidos de exercícios de fixação, pressupondo que os alunos aprendiam e eram capazes de reproduzir corretamente o que era ensinado. Essa forma de entendimento do professor ao ensinar química, tira do aluno a oportunidade de "ser mais" e se comprometer com $\mathrm{o}$ ato de aprender, mediante ao diálogo crítico e problematizador. $^{22}$ A falta de comprometimento do aluno e consequentemente o desinteresse pela aula de química, pode estar relacionada a pouca participação que possui no processo de conhecer. Nesse sentido, a abordagem problematizadora planejada pelos estagiários tinha o diálogo como o leme que conduz a prática pedagógica, fazendo com que o aluno fosse motivado a participar ativamente na resolução de situação-problema através da curiosidade e do espírito crítico. $^{23}$

A maneira como a disciplina de química vem sendo abordada, não desperta o interesse dos alunos, mesmo possuindo vários conteúdos relacionados ao nosso cotidiano. Além desse, outros fatores podem ser relacionados, como a ausência de aulas experimentais nas escolas, a falta de recursos multimídia e métodos interativos de aprendizagem, e a dificuldade em contextualizar os conteúdos apresentados aos alunos de forma coesa e crítica. ${ }^{24}$

Ao tratar a experimentação dentro de uma perspectiva freireana, percebe-se que uma de suas funções é mediatizar os educandos e o objeto cognoscitivo. ${ }^{23} \mathrm{E}$ nesse sentido, a experimentação deve ser uma estratégia de ensino problematizador do conhecimento. A atividade experimental constitui um dos aspectos chaves para o processo de ensino e aprendizagem das ciências. Considerando esse aspecto, nos cursos de formação devem esclarecer que o trabalho em laboratório não se limita ao caráter de receita simples, com ênfase exclusivamente na execução do conhecimento científico. ${ }^{25}$ Mas que se fundamenta na construção de conhecimentos a partir da discussão da relevância da aula desenvolvida, esclarecimento da problemática na qual se insere, a participação dos alunos na formulação de hipóteses e experiências de projeto, além da análise dos resultados. As respostas dos alunos com relação à aula experimental no ensino de Química foram importantes para a escolha das atividades a serem desenvolvidas na situação-problema 
pelos estagiários. A aula experimental compreendeu uma resposta encontrada com frequência nas três primeiras questões do questionário, a começar pelas falas dos alunos:

A3: "A falta de experiências químicas. Porque não entendo o que ela vem falando no quadro os exemplos, tinha que ter uma sala de química".

A4: "Que a gente nunca vai para o laboratório".

Os comportamentos observados de alienação e apatia são comuns dentro da sala de aula. ${ }^{26}$ Diante dessa situação, se sugere a utilização de atividades experimentais com formato cativante que atraiam e prendam a atenção do aluno. Esse tipo de atividade tem como objetivo romper com a inércia, a desatenção e apatia, servindo de "elo incentivador para que os estudantes se dediquem de uma forma mais efetiva às tarefas subsequentes mais árduas e menos prazerosas". ${ }^{26}$ Dificilmente 0 aluno terá motivação para aprender os conteúdos curriculares relacionados a uma atividade experimental se ele mesmo não vê relação com o seu contexto, ou que este é tratado de forma mecânica e abstrata, ou ainda baseado na memorização não voluntária. Há um desconexo entre o que o professor ensina e a experiência existencial dos alunos: ${ }^{26}$

"Os conteúdos são retalhos da realidade desconectados da totalidade em que se engendram e em cuja visão ganhariam significação. A palavra, nestas dissertações, se esvazia da dimensão concreta que devia ter ou se transformam em palavra oca, em verbosidade alienada e alienante. Daí que seja mais som que significação e, assim, melhor seria não dizê-la.". ${ }^{26}$

A Figura 3 evidencia que os alunos do ensino médio acreditam que para melhorar as aulas de química é necessário ter aulas práticas e interessantes $(56,0 \%)$ :

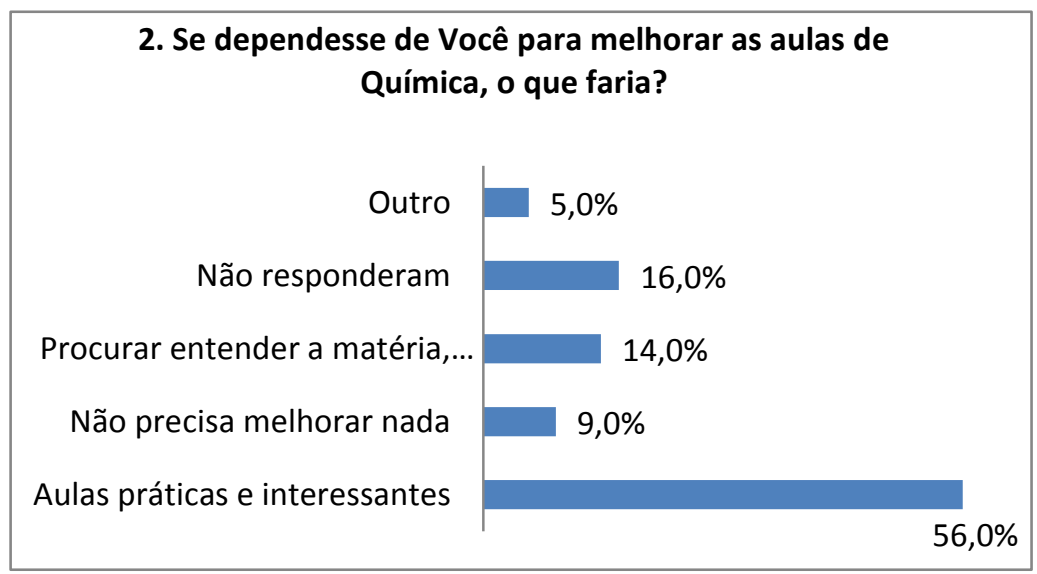

Figura 3. Resultado percentual das respostas dadas a questão 2 do questionário respondido pelos alunos do ensino médio. "Outro" representa respostas diversas ou os alunos não responderam

A experimentação vem adquirindo um caráter motivador, lúdico, que desperta a atenção e que aumenta a capacidade de aprendizado, ao envolver o aluno nos temas a serem trabalhados. Para esse autor, os professores devem tomar a experimentação como parte de um processo pleno de investigação em que o pensamento e as atitudes dos alunos fazem parte desse contexto. ${ }^{27}$ Os relatos dos alunos fazem 
referência à aula experimental como uma das formas principais de melhorar o ensino de química:

A5: "Gostaria de ir para um laboratório e aprendermos mais na prática o que a gente vê na sala".

A6: "Eu gostaria de trabalhar com experimentos, ter mais aulas práticas do que teórica, além de chamar nossa atenção, acho que aprenderíamos mais na prática do que na teoria."

Ao reconhecer que o experimento possui um papel fundamental em ativar a curiosidade dos alunos, pensemos essa atividade dentro de um contexto mais amplo da estratégia de ensino. A forma como o experimento é trabalhado, ilustrativa ou investigativa, poderá induzir os alunos a ampliar conhecimentos. ${ }^{28} \mathrm{E}$ assim confrontar as concepções de senso comum adquirido, e desenvolver o pensamento crítico diante da sociedade. Afirma ainda que ao realizar a experimentação ligando ao cotidiano do aluno, o professor sai do tradicionalismo, favorecendo a sua curiosidade e motivação.

A Figura 4 mostra que 33\% dos alunos citaram temas variados relativos ao meio ambiente e ao cotidiano: "efeito estufa; acidentes radiológicos; assuntos do dia-a-dia como fazer sabão em pó, shampoo, creme, amaciante; história da alquimia; drogas; explosões; funcionamento de leds; corpo humano; a química em nossa vida; e outros". Dentre as respostas apontadas pelos alunos, cerca de $29 \%$ se referiram a experimentos em laboratório.

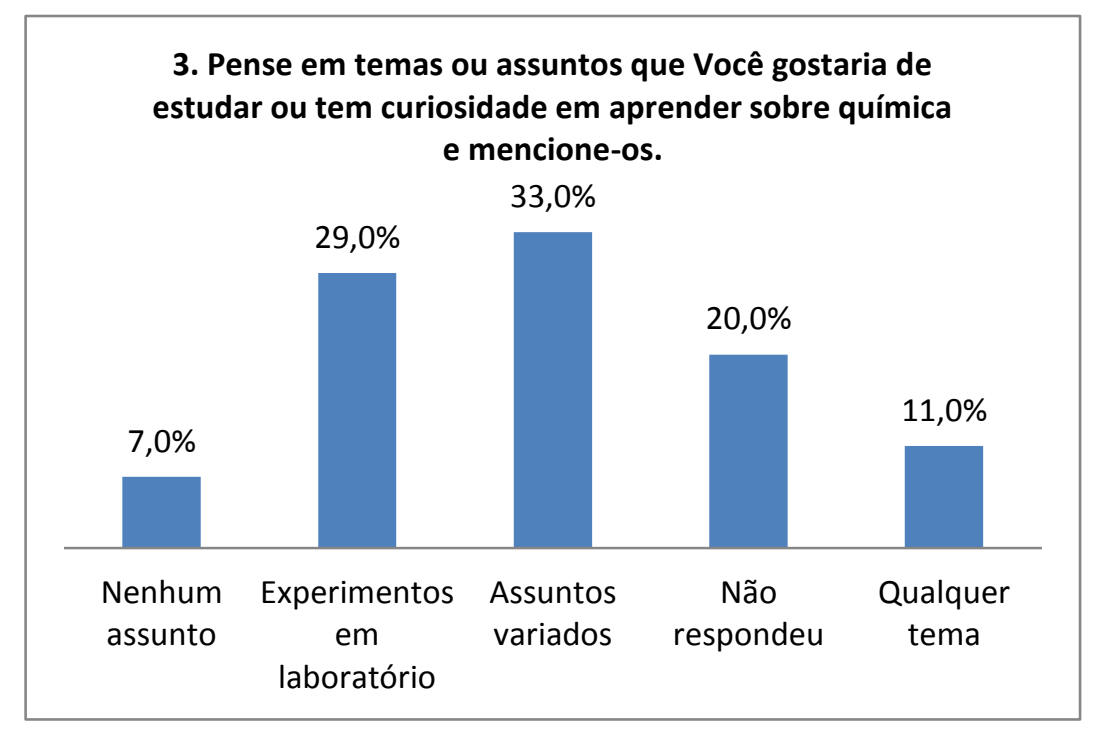

Figura 4. Resultado percentual das respostas dadas a questão 3 do questionário pelos alunos do ensino médio

Os relatos dos alunos fazem referência aos assuntos que gostariam de estudar ou possuem curiosidade em aprender sobre química:

A7: "Queria aprender mais sobre os experimentos que existe e que podemos fazer."
A8: "Eu queria saber como faz sabão em pó."

A9: "Tenho curiosidade de aprender o que eu uso no meu dia-dia como creme e shampoo."

Na Figura 5, podemos concluir que para a maioria dos alunos do ensino médio (44\%), a Química ajuda a responder aquilo que não 
sabem em seu cotidiano, $14 \%$ mencionaram que às vezes, mas para $34 \%$ afirmam que não ajuda em nada. A importância da química para a humanidade é notória e se reconhece alguns dos avanços alcançados: na área da saúde, aumentando a expectativa de vida das pessoas; na área ambiental, proporcionando a prevenção e correção de problemas ambientais, criando novos procedimentos e iniciativas integrados a "Química Verde"; a química da atmosfera, elucidando os efeitos causados pela combustão de combustíveis derivados do petróleo, e tantos outros problemas discutidos atualmente. ${ }^{29}$

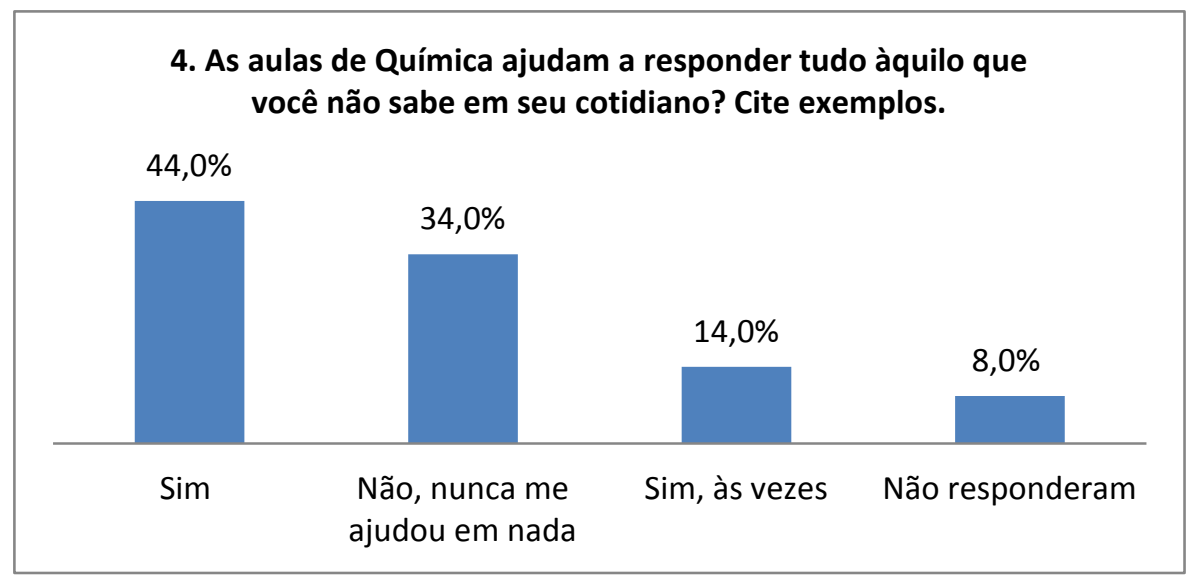

Figura 5. Resultado percentual das respostas dadas a questão 4 do questionário pelos alunos do ensino médio

Mesmo com tamanha importância para a humanidade, para alguns alunos, a química não ajuda a compreender o seu cotidiano, como mostra os recortes:

A10: "Não. Porque quase nada acontece no meu cotidiano pra colocar química no meio".

A11: "Não. Acho que aquilo que a gente tem que usar no nosso dia-a-dia não recebemos instrução".

Partindo dessa concepção de que a Química não ajuda a compreender nada, muitas vezes o problema dessa má interpretação, advém do próprio contexto educacional, onde o aluno se encontra, seja pela tendência educacional, seja pela prática docente, ou ainda por professores ministrarem aulas sem um discurso e sem reflexões críticas relacionados ao seu cotidiano. Esses relatos nos faz refletir sobre qual conhecimento queremos que os alunos adquiram? Esse conhecimento será em prol do quê e de quem? E, portanto, contra o quê e contra quem? ${ }^{3}$

Ao discutir os princípios freireanos, é preciso romper com o autoritarismo sem cair na permissividade, buscando uma educação tolerante e dialógica, desenvolvendo uma educação de qualidade e substancialmente democrática. 0 autoritarismo se refere à pedagogia da resposta (educação bancária) que na nossa visão deve ser superada pela educação libertadora que se alimenta da pergunta como um desafio. Nessa discussão, se defende a educação como um "ato político e de conhecimento na qual os alunos são chamados para analisar criticamente um objeto de estudo para que conheçam e possam agir sobre ele transformando-o". ${ }^{4}$

Nesse contexto, o estagiário precisa começar a refletir sobre o conteúdo necessário para o aluno aprender, elegendo como ponto de partida, o contexto do aluno que pretende de forma intencional trabalhar o necessário para aprender. ${ }^{30}$ No entanto, 
algumas práticas pedagógicas se apoiam na abordagem do cotidiano ao invés da contextualização para ensinar os conteúdos científicos. A abordagem do cotidiano ocorre através da exemplificação ou ilustração, o que nem sempre garante a aprendizagem do aluno e apreensão da realidade. Tais situações são utilizadas como introdutórias aos conteúdos teóricos, e possuem o objetivo exclusivo de chamar a atenção do aluno, aproveitando a motivação para ensinar os conteúdos.

O professor pode não só conhecer as necessidades do contexto na qual se encontra o aluno, mas incorporá-las com o desejo de transformar aquela realidade na qual está atuando. Ao analisar a realidade passa a ser não uma mera descrição dos fatos, mas sim uma aproximação da realidade que se encontra mais complexa do que nossas interpretações. Para apreender a realidade é necessário pesquisa, levantamento de hipóteses para explicar, podendo aplicar e criar novas teorias. ${ }^{31}$

$\mathrm{Na}$ quinta questão, os alunos responderam que seria necessário o professor refletir sobre: a indisciplina na sala de aula, as atividades pouco criativas e participativas, e o ensino descontextualizado e pouco interessante (Figura 6).

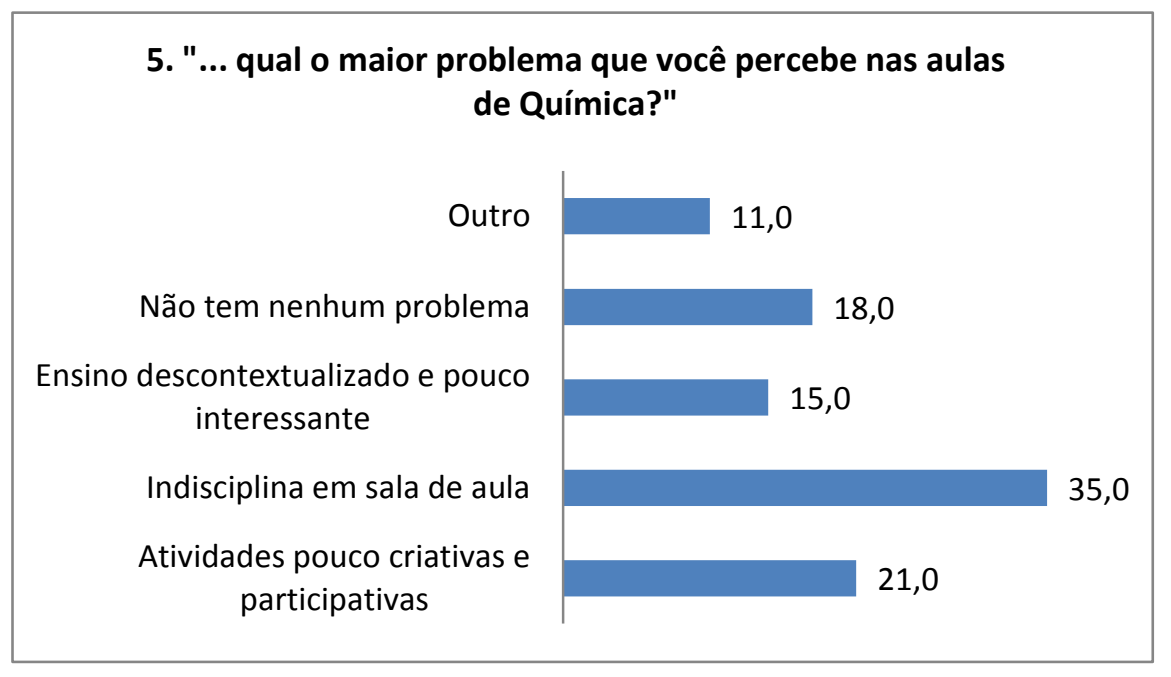

Figura 6. Resultado percentual das respostas dadas a questão 5 do questionário pelos alunos do ensino médio. "Outro" representa respostas diversas ou os alunos não responderam

A indisciplina apontada pelos alunos do ensino médio compreendeu o maior problema observado nas aulas de Química sendo necessário à reflexão do professor. Para os alunos construírem o conhecimento, é preciso um clima favorável e a educação possui dentro dos seus vários objetivos, o de ajudar os alunos a desenvolver-se eticamente numa perspectiva emancipatória. ${ }^{31}$

A falta de domínio do professor sobre os alunos produziu ao longo da história um conjunto de equívocos: castigos (palmatórias); humilhação como forma de melhor educar os alunos; a pressão através da avaliação do aluno e atualmente o enquadramento de alunos com hiperatividade ou déficit de atenção levandoos ao uso indiscriminado de medicamentos. ${ }^{31}$ Os professores não podem rejeitar ou menosprezar a reflexão sobre a disciplina que trabalham, buscando entender a problemática como sendo de todos e não somente da família ou da direção escolar.

A indisciplina na sala de aula é o discurso que mais se destaca entre os professores e os alunos. O motivo para tamanho problema no ensino, não se resume a um único fator isolado da realidade, mas a vários outros que 
se procura mostrar aos professores. ${ }^{31} \mathrm{~A}$ educação escolar é apenas um aspecto de um processo maior que exige do professor reconhecer os limites de suas abordagens, procurando complementá-los, e articulá-los com outras contribuições. Essa questão requer além dos saberes pedagógicos, a ajuda de outras áreas do conhecimento e nesse sentido fazer com que o aluno se perceba como ser participante das manifestações na sala de aula. ${ }^{31}$

Nesse sentido, é fundamental que o estágio supervisionado não se limite na observação e na tentativa de reprodução da prática ou na imitação de modelos já existentes. ${ }^{32}$ Mas que tenha condições para proceder à "análise crítica fundamentada teoricamente e legitimada na realidade social em que o ensino se processa". ${ }^{32}$ Assim, a observação do estagiário não se prende apenas à sala de aula, mas se aproxima do contexto em que a escola se encontra, aumentando as possibilidades de intervenção pedagógica crítica.

\subsection{Planejando a situação-problema}

Para a elaboração da situação-problema procurou-se, inicialmente, conhecer os estudantes mediante o questionário citado anteriormente e conversas com a professora regente das turmas de 30 ano (turmas A, B e C) do colégio. Por meio do questionário aplicado foi possível notar que os alunos sinalizam para a necessidade de aulas experimentais contextualizadas, criativas e participativas.

Nesse contexto, pensando em um tema gerador que viesse ao encontro da realidade do estudante e da escola e ainda, que fosse compatível com o plano de ensino já estabelecido para a série, os estagiários escolheram o tema envolvendo o meio ambiente: "A Chuva Ácida não contém somente Água". Com esse tema, os alunos passaram a estudar as substâncias ácidas e básicas no seu cotidiano, se posicionando criticamente com relação aos efeitos ambientais causados pelos gases produzidos a partir da atividade industrial, a fim de colaborar com as soluções para os problemas sociais. ${ }^{11}$ Para que o tema escolhido fosse interessante para todos os alunos ou pelo menos para a maioria, foi importante que o tema escolhido envolvesse o grupo e marcasse várias atividades. Dessa forma, a abordagem não vira rotina, e evita o desânimo na sala de aula, motivando o aluno para o ato de conhecer. ${ }^{34}$

O planejamento do tema para a abordagem problematizadora exigiu dos estagiários a clareza do trabalho que estava sendo proposto, contrapondo ao "fazer por fazer", e ao ensino mecânico e acrítico, incompatível com 0 ensino autêntico almejado. Neste sentido, o planejamento dessa abordagem foi constantemente discutido e criado pelos estagiários como sujeito ativo do processo, sem negar a participação dos alunos como também influenciadores da abordagem problematizadora planejada. Os resultados que apresentamos se referem à prática articulada a um plano de ação que os estagiários definiram, com isso novas leituras da realidade foi se fazendo, e buscando novas formas de intervenção.

3.3. Estratégia educativa relacionada à problematização: “A Chuva Ácida não contém somente Água"

O tema meio ambiente vem sendo discutido por várias disciplinas como a Química, Biologia, Geografia e outras, e é considerado como tema transversal obrigatório pelos Parâmetros Curriculares Nacionais (PCN). Dentro desse contexto, a chuva ácida vem sendo bastante abordada pelo fato de envolver conceitos de acidez e basicidade no ensino médio numa tentativa de aproximar a Química com os aspectos sociais e o contexto do aluno. Os conteúdos relacionados à chuva ácida permitem ao aluno compreender as transformações que 
ocorrem na atmosfera, desenvolvendo o senso crítico para a conservação e preservação do meio ambiente. ${ }^{33}$ Na primeira etapa de intervenção dos estagiários, foi explicado o objetivo das aulas e entregue a situação-problema aos alunos. A aula consistiu numa abordagem dialogada entre os estagiários e os alunos que participaram em grupo mediante a realização da atividade mostrada na Figura 7:

Atividade 1:

A partir das 18 figuras (figuras relacionadas à poluição causada pelas indústrias, pelos carros, etc.) organize-as de acordo com a evolução do processo de degradação ambiental, discuta com os colegas os possíveis problemas ao meio ambiente a partir do crescimento econômico e social, e explique a ordem considerada para a sua montagem na cartolina.

Figura 7. Primeira atividade realizada com os alunos do ensino médio a partir do tema "A Chuva Ácida não contém somente Água" (Imagens do Apêndice 1)

Nessa atividade foi possível compreender algumas das concepções prévias dos alunos sobre o crescimento das cidades, o aumento de carros nas ruas e consequentemente da poluição. Dentre as várias figuras que os grupos possuíam para a atividade, algumas eram da cidade de Goiânia, motivando a participação e a curiosidade dos alunos para discutirem como a nossa cidade veio se modificando ao longo dos anos. Os alunos elaboraram uma explicação para a ordem como as imagens foram aparecendo na apresentação e os estagiários acompanharam a aula até o desfecho do trabalho.

Os estagiários demonstraram surpresa com os alunos do ensino médio ao vê-los participando e perguntando na aula. Ao falar do diálogo na práxis, Paulo Freire menciona que a prática de perguntar é inerente à natureza humana, que expressa a curiosidade de conhecer, de se arriscar na vontade de descobrir novas experiências. ${ }^{36}$ Os relatos abaixo se referem as falas dos estagiários após a primeira intervenção com os alunos do ensino médio ( $E 1, E 2, \ldots$ se referem as falas dos estagiários):

E1: “... no nosso trabalho achei que surpreendeu muito mesmo, o interesse dos alunos, o que surpreendeu foi o entusiasmo do pessoal, eu tinha em mente que eles não iam se entusiasmar tanto assim com o projeto, eles ficaram pedindo mais aula, eles acharam muito interessante a nossa aula, eles cooperaram também, que é uma coisa muito difícil, eles cooperaram e tiveram criatividade, eles deram opinião interessante na aula, achei interessante."

E2: “A participação deles, o interesse, é o ponto positivo, deles percebi também da minha parte como professor que é necessário utilizar o conhecimento do aluno, porque muitas das vezes você está tendo uma aula dinâmica com eles ali e você percebe que alguns deles têm algumas ideias que você não teve e que aquilo de certa forma te traz a luz talvez daquilo que nem você ia falar, mas eles te alimentam de experiências e de alguns conceitos que você não lembra. Então percebi que é bom extrair dos alunos aquilo que eles sabem e que você pode utilizar aquilo, para realmente chegar a um consenso..."

Nesse contexto, o diálogo que se estabeleceu na sala de aula exigiu do estagiário a conscientização da postura assumida frente ao problema ambiental em estudo. Essa postura também passa a ser adotada pelos alunos à medida que procuram conhecer criticamente a sua prática social, e a partir dela passa a transformá-la. Para o segundo momento pedagógico, os alunos receberam a situação-problema elaborada pelos estagiários e a partir da sua leitura, a discussão do tema foi iniciada. Para a 
resolução da situação-problema era necessário que $\mathrm{o}$ aluno pesquisasse e refletisse sobre o problema que influenciou a extinção dos pássaros (Figura 8):

\section{Situação-problema:}

Em 1989 cientistas da Holanda noticiaram que um determinado pássaro canoro que habitava as florestas daquele país estava produzindo ovos com a casca fina e porosa. Problema similar fora detectado nas décadas de 60 e 70, causado pelo inseticida DDT. Durante as investigações não foi encontrada nenhuma evidência de intoxicação. Outra observação relevante foi a diminuição dos caramujos da região nessa época, deixando de ser a refeição principal dos pássaros da espécie canoro. Tente resolver esse problema, pesquise e mencione as possíveis causas da má formação das cascas nos ovos.

Figura 8. Situação-problema apresentada aos alunos do ensino médio na segunda etapa do trabalho a partir do tema "A Chuva Ácida não contém somente Água."

Para a resolução do problema, os estagiários planejaram iniciar uma discussão sobre o assunto "ácidos e bases" a partir de uma aula experimental. A aula experimental apresentada pelos estagiários foi elaborada e adaptada a partir do experimento "Investigando a produção da Chuva Ácida" publicada pelo Grupo de Pesquisa em Educação Química (GEPEQ) no livro Interações e Transformações I. ${ }^{35}$

Antes da realização dos experimentos os alunos em grupo apresentaram suas estratégias discutindo conjuntamente com outros grupos da sala de aula no intuito de determinar qual a estratégia mais eficaz para o desenvolvimento do experimento. A partir das estratégias formuladas procedeu-se a aula experimental que possibilitou ao aluno a observação, formulação de hipóteses e a prática de busca, análise e síntese de informações, questionamento e reflexão dos fatos observados. A Figura 9 mostra o experimento realizado pelos alunos do ensino médio.

De um modo geral, os alunos necessitaram de esclarecimentos sobre a formulação da estratégia e realização da aula experimental. Os estagiários em alguns momentos foram questionados pelos alunos e demonstraram a intenção de falar as respostas prontas, como vem sendo realizado na educação bancária. Na perspectiva freireana a condução da aula de um professor consciente e democrático que se opõe a dominação verbal, não pode se restringir apenas em falar. Esse professor deve incluir o ato de escutar no sentido de induzir no aluno a recriação de alguém que escuta, fala, questiona e critica, dentro de um novo contexto a ser seguido na sala de aula. No âmbito da ciência, os conhecimentos específicos da química discutidos na abordagem problematizadora foram: transformações químicas presentes na formação dos gases que interferem na produção da chuva ácida (reações de combustão); acidez da água e do solo; composição química da água ácida e do solo; na sequência foram estudados os ácidos e bases, suas respectivas fórmulas e nomenclaturas; conceito de indicadores ácidos e bases; e em relação a composição do solo, foi realizado o estudo da indisponibilidade de nutrientes e sua lixiviação; e a necessidade da correção da acidez a partir de reações de neutralização. Durante alguns dias o experimento realizado foi acompanhado pelos alunos que expressaram suas hipóteses e conclusões. A simulação da chuva ácida ocorreu a partir da queima do enxofre em um frasco coletor produzindo gás dióxido de enxofre $\left(\mathrm{SO}_{2}\right)$ e com a adição de água formou-se ácidos como ácido sulfuroso e sulfúrico, tornando o $\mathrm{pH}$ da água baixo $(\mathrm{pH}=5)$. As sementes de feijão 
foram molhadas separadamente com água $(\mathrm{pH}=7)$ e água ácida $(\mathrm{pH}=5)$ proveniente da reação de combustão do enxofre. A determinação do $\mathrm{pH}$ foi realizada utilizando- se o papel indicador universal de $\mathrm{pH}(\mathrm{pH}$ 0-14 Cx.C/100 Tiras Merck), como mostra a Figura 10.

\section{Experimento 1}

1. Você acha que a chuva ácida é capaz de influenciar o meio ambiente? De que forma?

2. Como poderíamos analisar se a chuva ácida interfere na germinação de sementes e no crescimento das plantas? Crie uma estratégia para analisar esse fenômeno.

Materiais disponíveis: algodão, copos de plástico, sementes (feijão, milho ou sementes do cerrado), água, enxofre, papel indicador universal, fósforo, recipiente de vidro.

Perceba cada detalhe das sementes, anote todas as suas observações a cada dia de aula transcrevendo para a folha de acompanhamento o que foi discutido com o grupo. Mencione as hipóteses e anote as conclusões. Estratégia para analisar o efeito da chuva ácida na plantas: germinação de sementes e no crescimento das

Acompanhamento diário do efeito da chuva ácida:

\begin{tabular}{|c|c|c|}
\hline Dia/Mês & Observações & Hipóteses \\
\hline & & \\
\hline
\end{tabular}

Conclusão:

\section{Experimento 2}

1. Os ovos dos pássaros são constituídos por $\mathrm{CaCO}_{3}(94$ a $96 \%), \mathrm{MgCO}_{3}(\sim 1 \%)$ e $\mathrm{Ca}_{3} \mathrm{PO}_{4}$ ( $1 \%)$, além de glicoproteínas ( $4 \%$ ). A chuva ácida pode interferir no desenvolvimento dos ovos? Como? Crie uma estratégia para analisar esse fenômeno utilizando os produtos disponíveis.

Materiais disponíveis: ovos de galinha, pombo ou codorna; enxofre sólido; recipientes de vidro, fósforo e água.

Perceba cada detalhe, anote todas as observações a cada dia de aula transcrevendo para a folha de acompanhamento o que foi discutido com o grupo. Mencione as hipóteses e anote as conclusões.

Estratégia para analisar o efeito da chuva ácida nos ovos:

Acompanhamento do efeito da chuva ácida:

\begin{tabular}{|c|c|c|}
\hline Dia/Mês & Observações & Hipóteses \\
\hline & & \\
\hline
\end{tabular}

Conclusão:

Figura 9. Aula experimental “A Chuva Ácida não contém somente Água” 


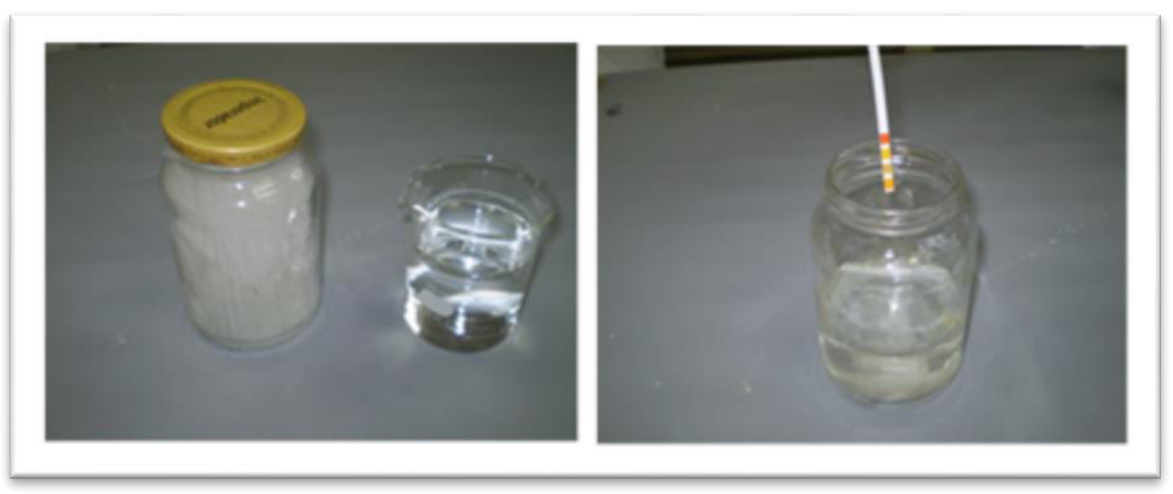

Figura 10. Simulação da chuva ácida a partir da queima do enxofre em pó e adição de água

Para a compreensão dos alunos, o estagiário que coordenava a aula, questionou cada momento do experimento na perspectiva do aluno refletir e entender os conhecimentos teóricos integrados à prática. E esses associados aos problemas ambientais, como a lixiviação do solo podendo afetar regiões de produtividade como em lavouras de feijão, soja e milho, diminuindo a oferta desses alimentos para a população e o seu reflexo na economia brasileira, além de outros problemas. A Figura 11 mostra a diferença de crescimento das sementes de feijão quando molhadas com água em $\mathrm{pH}$ igual a 5 e 7 por alguns dias.
(A)

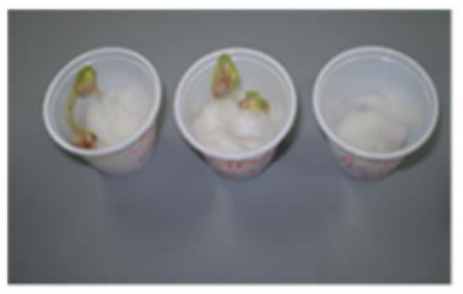

(B)

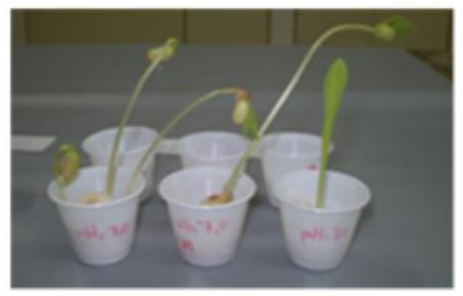

Figura 11. Crescimento das sementes de feijão com água (A) em $\mathrm{pH}=5$ e água (B) em $\mathrm{pH}=7$

$\mathrm{Na}$ nova visão da situação-problema, foram trabalhados os itens com aspecto sócio-ambiental relacionado à chuva ácida e ao solo como: a extinção de animais e plantas; déficit na produtividade e consequentemente a baixa oferta de alimentos à sociedade, acarretando um impacto maior para as famílias de baixa renda; ações individuais e governamentais para amenizar as consequências desse problema ambiental. Para a resolução da situação-problema, os estagiários promoveram uma aproximação: das conclusões dos alunos mediante as suas concepções prévias e as conclusões da aula experimental desenvolvida; a discussão na aula teórica abordando aspectos sociais e ambientais, integrada aos aspectos da ciência (conceitos químicos) foi necessária para alcançarem à resolução do problema (Figura 12): 
$\mathrm{Na}$ situação-problema o aluno será motivado a pesquisar sobre Holanda no período da industrialização, compreendendo as principais atividades poluidoras da época. Levantará os reais problemas desencadeados a partir do solo ácido, como a indisponibilidade de alguns nutrientes (especialmente fósforo, cálcio e molibdênio) e a toxidez de alumínio e manganês, além da correção da acidez; e outros assuntos relacionados.

A chuva ácida que incidiu nesse país provocou o aumento da acidez do solo passando a conter quantidade baixa de cálcio. Os pássaros que se alimentavam de caramujos, fonte de cálcio que representava um componente importante para a sua dieta alimentar, havia praticamente desaparecido das florestas. O solo seco contém normalmente de 5 a 10 gramas de cálcio por quilograma. O cálcio daquela região havia caído para cerca de 0,3 grama por quilograma de solo, um nível muito baixo para que os caramujos sobrevivessem e fossem fonte rica de cálcio para os pássaros. Consequentemente os pássaros passaram a se alimentar de outras espécies menos ricas em cálcio, o que levou a formação de ovos de casca fina e porosa, acarretando provavelmente a sua extinção.

Figura 12. Resolução da situação-problema apresentada aos alunos do ensino médio

Para alguns alunos as conclusões se limitaram apenas à observação do experimento (nível macroscópico). Para vários pesquisadores o conhecimento químico vem sendo trabalhado sem correlação entre as aulas teóricas e experimentais, e a devida transposição do nível microscópico ao macroscópico. ${ }^{36-38}$ Nesse sentido, os alunos passaram a realizar a aula experimental sem entender a relação com os conceitos químicos trabalhados na teoria, como mostra o recorte:

A12: "Na minha opinião, a água ácida impediu que a semente germinasse, criou fungo porque aqui é fechado, e que não germinou deteriorou a semente, e com $\mathrm{pH} 5$ até começou a desenvolver mas não ficou tão grande quanto essa aqui (apontou para uma amostra molhada com água normal, o feijão germinou e cresceu bem mais) essa com água normal cresceu $12 \mathrm{~cm}$ e a outra molhada com água ácida cresceu apenas $4 \mathrm{~cm}$, e quanto mais ácida menos chance de desenvolver com $\mathrm{pH} 5$ desenvolveu pouco, ficou muito pequeno."

$\mathrm{Na}$ resolução da situação-problema muitos alunos apresentaram respostas plagiadas da internet sem nenhuma relação com a solução do problema ou que esboçasse uma tentativa de interpretação. Essa prática é muito comum no ensino bancário, visto que os alunos estão acondicionados a realizarem as supostas "pesquisas" sem analisarem criticamente. As aulas tradicionais são realizadas com a transferência de conhecimento, raramente os alunos são provocados por uma reinvenção criativa, de modo excitante, que os obrigue a repensar a maneira de ver a realidade. Em outros casos podemos perceber aproximações mais corretas, como no comentário do aluno:

A13: "A má formação é causada pela chuva ácida que entra em contato com os ovos, modificando seu conteúdo molecular fazendo com que a casca do ovo fique mais fina e porosa. A diminuição da refeição principal dos pássaros da espécie canoro pode ter sido causada também pela chuva ácida. Com a diminuição das suas refeições os ovos na sua fase de formação ficaram mais fracos, pois a quantidade de alimento ingerida seria menor, logo haverá uma má formação das cascas dos ovos."

\section{Considerações Finais}

A análise da aula desenvolvida pelos estagiários sob o princípio problematizador permitiu verificar as contribuições que uma atividade experimental pode trazer para o ensino de Química, como por exemplo: a maior participação e interação do estagiário 
com o aluno em sala de aula; valorização da aprendizagem de atitudes e não apenas de conteúdos; criação de conflitos cognitivos em sala de aula despertando para o conhecimento crítico, desenvolvimento da consciência crítica, entre outros.

Podemos ressaltar, ainda, uma característica importante na abordagem problematizadora: a relação aluno-objeto. Em um laboratório tradicional, o aluno deve seguir instruções (de um manual ou do professor) sobre as quais não tem nenhum poder de decisão, seguindo uma série de passos propostos, deve chegar a um objetivo predeterminado, a respostas conhecidas pelo professor. Já na abordagem problematizadora como atividade experimental, o estagiário entende que o aluno pode ser levado a criar sua autonomia de pensamento. Nela o aluno do ensino médio participa do processo de aprendizagem, sai de uma postura passiva e começa a perceber e agir sobre o seu objeto de estudo, relacionando o objeto com acontecimentos e buscando as causas dessa relação, aprende a "ser mais".

A problematização desenvolvida neste trabalho evidencia que desde o início do processo de estudo, que começa na observação da realidade, até o momento final de atuação sobre essa mesma realidade, aconteceu em graus variados, com uma mobilização intelectual, afetiva, política e social dos estagiários. 0 processo veio acrescentar no conjunto de saberes dos estagiários e alunos, um método de estudo e de leitura da realidade com consequências relevantes para sua prática efetiva de cidadão crítico. Os estagiários, com uma consciência ingênua enraizada pela cultura do capitalismo que prepara seus professores para apenas transmitir conhecimentos, emerge a partir do processo dialógico instalado. $E$ nesse sentido, inicia-se a superação da visão simplista de ver as coisas, na tentativa de refletir e agir sobre os problemas que envolvem o professor, a escola e a sociedade.

\section{Referências Bibliográficas}

${ }^{1}$ Freire, P.; Pedagogia da Autonomia: Saberes Necessários à Prática Educativa; 4a. ed., São Paulo: Paz e Terra, 2001.

${ }^{2}$ Neves, N.; Rossi, L. A. S. A educação libertadora como instrumento de emancipação do ser humano: uma releitura do livro de Jó a partir dos conceitos de Paulo Freire. Ciberteologia - Revista de Teologia \& Cultura 2010, 31, 14. [Link]

${ }^{3}$ Freire, P.; Educação como prática da Liberdade. 14a. ed., Paz e Terra: Rio de Janeiro, 1983.

${ }^{4}$ Guerreiro, M. E.; Sonhos e Utopias: Ler Freire a partir da Prática. 1a. ed., Livro Editora: Brasília, 2010.

${ }^{5}$ Freire, P.; Conscientização: Teoria e Prática da Libertação: uma Introdução ao Pensamento de Paulo Freire. 1a. ed., Cortez \& Moraes: São Paulo, 1979.

${ }^{6}$ Freire, P.; Educação e Mudança. 12a. ed., Vozes: Petrópolis, 1984.

${ }^{7}$ Freire, P.; Pedagogia do Oprimido. 50a. ed., Paz e Terra: Rio de Janeiro, 2011.

${ }^{8}$ Gadotti, M. Lições de Freire. Revista da Faculdade de Educação 1997, 23, 1. [CrossRef]

${ }^{9}$ Lima, J. O. G; Leite, L. R. O processo de ensino e aprendizagem da disciplina de química: o caso das escolas do ensino médio de Crateús/Ceará/Brasil. Revista Eletrônica de Investigación en Educación em Ciencias (REIEC) 2011, 7, 72. [Link]

${ }^{10}$ Maldaner, O. A; Piedade, M. C. T. Repensando a Química. Química Nova na Escola 1995, 1, 15. [Link]

${ }^{11}$ Santos, W. L. P.; Schnetzler, R. P.; Educação em Química: Compromisso com a Cidadania. 3a. ed., Unijuí: RS, 2003.

${ }^{12}$ Carvalho, A. M. P; Gil-Pérez, D.; Formação de Professores de Ciência. Cortez: São Paulo, 1993.

${ }^{13}$ Chassot, A. I.; Para que(m) é Útil o Ensino? Alternativas para o Ensino (de Química) mais Crítico. Ulbra: RS, 1995. 
${ }^{14}$ Freire, P; Shor, I.; Medo e Ousadia: o Cotidiano do Professor. 7a. ed., Paz e Terra: RJ, 1986.

${ }^{15}$ Freire, P.; Extensão ou Comunicação? $5 a$. ed., Paz e Terra: RJ, 1980.

${ }^{16}$ Azevedo, M. C. P. S.; Ensino por Investigação: Problematizando as Atividades em Sala de Aula. In: Anna Maria Pessoa de Carvalho. Ensino de Ciências: Unindo a Pesquisa e a Prática. Pioneira Thomson: SP, 2003, cap. 2.

${ }^{17}$ Zitkoski, J. J.; Paulo Freire \& Educação. $2^{\text {a }}$ ed., Autêntica Editora: Belo Horizonte, 2010.

${ }^{18}$ Pimenta, S. G.; Ghedin, E. (orgs.).; Professor Reflexivo no Brasil, 4a. ed., Cortez: SP, 2006.

${ }^{19}$ Moraes, C. R.; Varela, S. Motivação do Aluno Durante o Processo de EnsinoAprendizagem. Revista Eletrônica de Educação 2007, 1, 1. [Link]

${ }^{20}$ Freire, P.; Política e Educação: Ensaios. 5a. ed., Cortez: São Paulo, 1993.

${ }^{21}$ Ferreira, A. O.; Souza, M. J. J. A redefinição do papel da escola e do professor na sociedade atual. Vértices 2010, 12, 165. [CrossRef]

${ }^{22}$ Freire, P.; Educação e Atualidade Brasileira. $3^{\text {a }}$ ed., Cortez: São Paulo, 2003.

${ }^{23}$ Francisco Júnior, W. E.; Analogias e Situações Problematizadoras em Aulas de Ciências. 1a. ed., Ed. Pedro \& João Editores: São Carlos, 2010.

${ }^{24}$ Carvalho, H. W. P.; Batista, A. P. L.; Ribeiro, C. M. Ensino e aprendizado de química na perspectiva dinâmico interativa. Revista Experiências em Ensino de Ciências 2007, 2, 34. [Link]

${ }^{25}$ Carrascosa, J.; Gil-Pérez, D.; Vilches, A. e Valdés, P. Papel de la actividad experimental en la educación científica. Caderno Brasileiro de Ensino de Física 2006, 23, 157. [Link]

${ }^{26}$ Laburú, C.E. Fundamentos para um experimento cativante. Caderno Brasileiro de Ensino de Física 2006, 23, 382. [Link]

${ }^{27}$ Giordan, M. O papel da experimentação no ensino de ciências. Química Nova na Escola 1999, 10, 43. [Link]
${ }^{28}$ Uchôa, A. M.; Nascimento, R. F. Passando um "cafezinho": misturas e separação de misturas a partir de um experimento com materiais do cotidiano. Vivências 2012, 8, 181. [Link]

${ }^{29}$ Silva, L. A.; Andrade, J. B. Química a serviço da humanidade. Cadernos Temáticos de Química Nova na Escola 2003, 5, 1. [Link]

30 Jimenez-Liso, M. R.; Manuel, E. La química cotidiana, una oportunidad para el desarrollo profesional del professorado. Revista Electrónica de Enseñanza de las Ciencias 2009, 8, 878. [Link]

${ }^{31}$ Vasconcellos, C. S.; Indisciplina e Disciplina Escolar. 1a. ed., Cortez: São Paulo, 2009.

${ }^{32}$ Pimenta, S. G.; Lima, M. S. L.; Estágio e Docência. $7^{a}$ ed., Cortez: São Paulo, 2012.

${ }^{33}$ Maia, D. J.; Gazotti, W. A.; Canela, M. C.; Siqueira, A. E. Chuva ácida: um experimento para introduzir conceitos de equilíbrio químico e acidez no ensino médio. Química Nova na Escola 2005, 21, 44. [Link]

${ }^{34}$ Freire, P.; A Importância do Ato de Ler: em três Artigos que se Completam. 23a. ed., Cortez: São Paulo, 1987.

${ }^{35}$ Pitombo, L. R. M.; Marcondes, M. E. R.; Interações e Transformações I - Elaborando Conceitos sobre Transformações Químicas. 5a. ed., Edusp: São Paulo, 2005.

${ }^{36}$ Giordan, M.; Góis, J. Telemática educacional e ensino de química: considerações sobre um construtor de objetos moleculares. Linhas Críticas 2005, 11, 285. [Link]

${ }^{37}$ Santos, W. L. P.; Schnetzler, R. P. Função social: o que significa ensino de química para formar o cidadão? Química Nova na Escola 1996, 4, 28. [Link]

${ }^{38}$ Souza, K. A. F. D.; Cardoso, A. A. Aspectos macro e microscópicos do conceito de equilíbrio químico e de sua abordagem em sala de aula. Química Nova na Escola 2008, 27, 51. [Link]

${ }^{39}$ Candau, V. M. A formação de educadores: uma perspectiva multidimensional. $\mathrm{Em}$ Aberto 1982, 1, 19. [Link] 